\title{
Antropología, ciencia y otro conocimiento. Reflexión sobre el sujeto y sus conceptualizaciones
}

\author{
Francisco Javier Gómez Carpinteiro* \\ ICSYH-BUAP
}

En este artículo, planteo que la antropología social tiene que superar el empirismo de la cosa observada, pues tal epistemología contribuye a la clasificación de sujetos para su control. En contraposición, argumento que existe otro conocimiento con un carácter desafiante. Desarrollo esta idea a través de la respuesta a las siguientes cuestiones: 1) qué nos impide hacer explícitos nuestros compromisos éticos y políticos; 2) cómo superar nociones sustentadas en la cientificidad para incorporar experiencias de lucha de sectores subordinados, generalmente estudiados por los antropólogos; y 3) cómo crear conceptos basados en tales experiencias que desborden los entendimientos sobre el sujeto sustentados por una producción académica e intelectual dominantes.

(Sujeto como lucha, trabajo de campo, otra epistemología, identidad clasificatoria, La otra campańa zapatista, Estado)

n este trabajo sostengo la necesidad de una antropología que trascienda la visión empirista de la cosa observada. Con un analisis así, se pueden superar las clasificaciones uniformadoras de una narrativa académica e intelectual dominante, en la cual las personas están atadas al horizonte de la democracia liberal. En dicha narrativa, otras formas de conocimiento provenientes de los

*panchog39@hotmail.com Agradezco a Andrew Roth me haya tomado en cuenta en su interés por propiciar una reflexión sobre las relaciones entre ética y conocimiento antropológico, especialmente en estos momentos que se requieren diálogos y debates. También doy las gracias a los revisores anónimos de este documento. Sus críticas muy agudas ayudaron a reorientar y precisar mis ideas. Por supuesto, asumo la responsabilidad de todo lo escrito aquí. 
"objetos de estudio" son consideradas sin estatus epistemológico y, por lo tanto, negadas, mientras que la historicidad de conceptos analíticos que refuerzan sus propias argumentaciones no son materia de un examen crítico.

Para desarrollar mi argumentación delineo interrelacionadamente la respuesta a tres cuestiones. La primera es pensar hasta qué grado sustentar un realismo basado en la objetividad, que indique la verdadera especificidad histórico-estructural del sujeto, corresponde a compromisos políticos y éticos de analistas que generalmente no se hacen explícitos. La segunda concierne a cómo desbordar nociones, sustentadas en ideas de cientificidad, para introducir las experiencia de lucha de sectores explotados y sojuzgados.

Finalmente, la tercera plantea en qué sentido otras formas de conocer, no atadas a los cánones metodológicos de una disciplina sobre la otredad, desbordan conceptos que hacen a las personas legibles y gobernables, lo que devela tanto la operación de poderes académicos en formas de categorización de sujetos, como las luchas de éstos por negar su estandarización en un mundo paradójicamente desigual. Pensar al sujeto como un concepto crítico implica reconocer que la construcción de conocimiento está atravesada por la existencia del antagonismo de clase, por lo cual la creación de saberes es un lugar de lucha. La afirmación dicha arriba parecería arriesgada. Sin embargo, tiene como sustrato la visión autocrítica de Marx sobre lo que pudiera concebirse como la "verdad" perseguida por el cambio revolucionario del "socialismo científico". Dicha autorreflexión de los peligros de pensar al marxismo como ciencia (peligros que terminaron en tragedias humanas) fue generada por Marx en su intelocución con los populistas rusos al final de su vida, donde subraya su optimismo en la existencia de una creatividad política capaz de esforzarse por su liberación (véase Shanin 1983, 283, 272).

$\mathrm{El}$ artículo se compone de cuatro partes. En la primera ofrezco un acercamiento a lo que en los últimos años ha sido debatido en el seno de la influyente antropología anglosajona en torno a lograr relatos sólidos sobre la desigualdad y las formas de resistencia o lucha a través de la definición de la distancia social entre el etnógrafo y el "otro" (político). En la segunda emprendo una reflexión sobre con- 
ceptos que contienen cargas de significados ideológicos, anuncian la racionalidad de una época y establecen lo coherente para el dominio. En la tercera, presento un ejemplo de la generación de un pensamiento desafiante sobre el sujeto, enraizado a su experiencia histórica, a través de lo que "La otra campaña" zapatista significó en el 2006 para diversas poblaciones subordinadas. Por último, interpreto lo que un conocimiento sencillo y sensible sobre las traducciones locales de la historia universal, inscrita en la formación del Estado y el desarrollo capitalista, representa para un entendimiento reflexivo y documentado de la construcción compleja de un orden de dominación y la potencialidad que existe en sujetos conscientes de sus propias voces para desafiarlo e imaginar futuros más dignos.

Tengo claro que cada aspecto delineado arriba representa una temática en sí misma, con sus propios problemas, amplios desafíos y profundos desarrollos. Por consiguiente, no buscó agotar el tratamiento de cada una de ellas. Aspiro unicamente a abrir vetas de reflexión para una antropología más autocrítica de sus postulados y quehaceres en un presente tan injusto, convulsionado y violento.

\section{ANTROPOlOGÍA Y RESISTENCIA: ENTRE VERDAD Y ÉTICA}

La antropóloga norteamericana Sherry Ortner (2006, 43), inspirada en lo que Clifford Geertz entendía como descripción densa -la riqueza, exhaustividad y detalle que debería contener el relato etnográfico-, cuestiona la aparente falta de rigurosidad y profundidad en diversos estudios de la resistencia. En el foco de su crítica caben tanto los análisis de la "infrapolítica" de James C. Scott, como los estudios subalternos (Subaltern Studies) y las orientaciones del marxismo cultural influenciadas por Raymond Williams.

Además de cuestionar que estos análisis no rebasan la dicotomía entre dominados y dominadores, Ortner indica la escasez de datos en torno a las propias fricciones y tensiones que caracterizan a los grupos subordinados, el incorrecto tratamiento de la cultura, así como la imposibilidad de abordar fuentes variadas que impiden observar la expresión política más amplia del sujeto. Su conclusión es categórica. La mayoría de estudios que se orientan a estudiar la resis- 
tencia no logran construir un relato que objetivamente dé cuenta de las intenciones, los deseos, temores y proyectos de los actores envueltos en diversos dramas sociales, básicamente por no abordar las cuestiones de las políticas internas de esos grupos y estar sumidos en una crisis de representación que impide la posibilidad de lograr verdaderos retratos sobre el otro (Ortner 2006, 61-62).

Al tomar el modelo de Geertz (1990 [1973]) como paradigmático para comprender la naturaleza y dinámica de significados de prácticas políticas en términos exhaustivos y holísticos, Ortner deja asentada la distancia social que media entre el investigador y las personas que resisten, bien ilustrada en la conseja geertzina de observar las acciones sobre los hombros de la gente "local". Para una disciplina como la antropología, inmersa en el carácter subjetivo e intersubjetivo del registro y análisis de pautas culturales, una posición como la de Ortner tiene que valorarse - mucho más en contextos explícitamente conflictivos y políticos- para establecer si sus declaraciones epistemológicas reditúan verdaderamente en la reconstrucción de la singularidad histórica de los subalternos, incluyendo sus propias contradicciones internas.

La dimensión moral ha sido un componente central en los relatos sobre la diferencia humana que algunas antropólogas y antropólogos anglosajones han desarrollado en los últimos años. Imbuidos de eso que llama Ortner la existencia de una "crisis de representación" han buscado nuevos tipos de relatos en los cuales el antropólogo o antropóloga aparezca como un atento escucha y observador, testigo de tragedias y comprometido con los dilemas que atraviesan en sus vidas cotidianas gente pobre o marginal.

Una obra paradigmática al respecto es la de Nancy ScheperHughes (1992). Por supuesto, posturas como la de esta autora han acarreado severas críticas de diversos sectores de la antropología anglosajona. $\mathrm{Al}$ respecto, es interesante el debate suscitado en torno a la objetividad y la militancia en una de las revistas más influyentes de la disciplina en Estados Unidos. En esa polémica, D’Andrade (1995), teniendo como referencia los trabajos de Scheper-Hughes, cuestiona que la antropología se haya tornado de "modelo" objetivo para el entendimiento del mundo a un modelo "moral", en el cual 
prevalecen orientaciones para distinguir lo que es bueno de lo malo. En este sentido, si ahora el propósito es la "denuncia" de condiciones que genera la "opresión"; la crítica hacia la "objetividad" se da por suponer que representa un medio para enmascarar la opresión.

D’Andrade $(1995,406)$ identifica la génesis de ese modelo moral en las ideas que Jeremy Bentham ofreció a finales del siglo XVIII para la identificación de símbolos que el gobierno utiliza para la mistificación, con el objeto de esconder "intereses siniestros" para dominar, una idea que incluso Marx utilizó en su "propio modelo de conflicto social y su resolución a través del socialismo”. Según D'Andrade (1995, 406-407), el modelo de Bentham en la antropología empotró durante los sesenta y setenta con las ideologías de intelectuales norteamericanos de izquierda (críticos de la guerra de Vietnam). Un ejemplo notable de eso fue el libro editado por Dell Hymes, Reinventing Anthropology. Más tarde, en los ochenta, resurgió con el movimiento posmoderno, que bajo el impulso de la deconstrucción y la búsqueda de nuevas formas de representación, tuvo en el libro Writing Cultures, editado por Clifford y Marcus en 1986, su más importante heraldo.

Un aspecto relevante de la crítica de D'Andrade $(1995,407)$ es indicar que el modelo moral no ofrece una buena representación de lo que actualmente es la realidad, en virtud de que existe un tiempo diferente determinado por la consumación de la confrontación ideológica con el fin de la guerra fría. Si las diferencias antes fueron ideológicas, una concepción del mundo basada en el estilo gramsciano, por ejemplo, es inadecuada para entender las disrupciones que implicó el desbaratamiento de la Unión Soviética. En otras palabras, en estos momentos es irrelevante identificar la opresión en virtud de que el problema fundamental para cualquier macroteoría es el fracaso de los actuales gobiernos para mantener el orden. No obstante, si es que impera una situación para denunciar la mistificación de modos de opresión esto es razonable en la discriminación por cuestiones raciales y sexistas (D’Andrade 1995, 407). ${ }^{1}$

${ }^{1}$ Más recientemente Hale $(2007,42-51)$ ha planteado en sus investigaciones sobre Guatemala una "metodología de investigación comprometida". Sugiere la participación directa del "sujeto de investigación" como interlocutor no sólo en el diseño del estudio, 
Aunque parten de perspectivas contradictorias, tanto el modelo que plantea D'Andrade como el de las propuestas de la antropología interpretativa y posmoderna no son tan distintos entre sí. Tales similitudes reposan en una idea compartida de representación. En ambos enfoques, el contexto de poder desde donde emerge el texto antropológico no es referido históricamente. Además, los argumentos que estructuran esos textos no se ligan a conceptos y categorías que tienen relación con el control de poblaciones en contextos de fragmentación generados por el capital.

Michel-Rolph Trouillot (2003), un antropólogo de origen caribeño, crítico de las formulaciones basadas en la cultura, propias de la antropología estadounidense, que se afanan en su uso para esconder las cuestiones de clase e historia en sus análisis particularmente dentro y fuera de Estados Unidos, cuestiona el distanciamiento entre el antropólogo y los subordinados que supone una recreación del debate entre objetividad y compromiso político. El argumento de Trouillot articula dos asuntos vinculados entre sí. En primer término, critica la fetichización del trabajo de campo, que es reducido a la epistemología empiricista de la cosa observada; es decir, a la observación de la locación antropológica que sustituye una comprensión histórica para exhibir los marcadores globales que hacen ser a ésta, sin embargo, única o singular. En segundo lugar, cuestiona el rechazo a dotar de estatus epistemológico a las "voces nativas".

La creencia generalizada de que las poblaciones observables sólo tienen información empírica y experiencias fenomenológicas refleja la elección ética y política que hace individualmente el antropólogo. El sustrato para esta idea se encuentra vinculada a ese amplio espectro de la disciplina antropológica de estar atrapada entre las ciencias sociales duras y las humanidades. Sin embargo, tal condición parece conferirle la competencia para captar la voz de los nativos. Tal asun-

su desarrollo y evaluación de sus resultados, sino también en la reflexión de lo que supone el constante cruce de fronteras personales en el trabajo de campo entre el investigador, las diversas gentes estudiadas y entre ellas mismas, con el fin de entender la naturaleza del "punto de vista" que emana de lo que pudieran ser encuentros y desencuentros. Sin embargo, en la perspectiva de Hale, no hay la renuncia explícita a las convenciones de método seguidas en la antropología para lograr la objetividad. 
to es puesto de relieve en el comentario de Geertz (1990 [1973], 372), acerca de que la pelea de gallos en Bali es "una lectura de la experiencia baliesa, una historia de ellos que se cuentan a sí mismos" y, por ende, un acto que el etnógrafo lee "por encima" de los hombros de los nativos. Con respecto a esta posibilidad de interpretación, Trouillot $(2003,130)$ tiene un cuestionamiento.

Si en los marcos de una etnografía realista esta ilusión de captar el punto de vista de las personas implicó un registro objetivo (científico), la crítica posmoderna convirtió el relato etnográfico realista en un género literario, dentro del cual, como el propio Geertz buscaba verse, el antropólogo era un tipo de autor preparado para la comprensión de la cultura como un ensamble de textos. Autoinstituido como un literato o un crítico literario debido a una función más aguda de observador, el etnógrafo continuó con el rechazo en reconocer un estatus epistemológico a la voz nativa. Acerca de esto, Trouillot $(2003,132)$ cuestiona que si la labor de un critico literario de obras como las de Baudelaire o Joyce, no impide sino contrariamente impulsa que los demás lectores se acerquen a esos autores, por qué las personas que estudian los antropólogos no pueden ser vistas entonces como interlocutores válidos que, al igual que Baudelaire, tienen el derecho a pensar o escribir sobre la modernidad. En suma, en tanto que antropólogos con pretensiones positivistas tendieron a dotar de pasividad a sus objetos de observación, los antropólogos interpretativos y posmodernos silenciaron los alcances de la voz nativa o las voces nativas para enunciar la suya como la única válida.

De este modo, lo que pudiera esconder la forma de dotar de fuerza a un relato sobre la diferencia es la retórica de que la voz de los nativos es dominada por la voz del etnógrafo. Por consiguiente, para Trouillot $(2003,132)$ la mención de la lectura detrás de los hombros de los otros -hecha por Geertz- refleja tanto un distanciamiento social con respecto a lo que se registra como una recreación de una relación asimétrica entre el investigador y el investigado, lo que deja ver un uso del dato fenomenológico descontextualizado de las relaciones de poder. Por esa razón, Trouillot $(2003,132)$ con ironía plantea literalmente sobre esa metáfora de Geertz: "Los antropólo- 
gos en verdad permanecen atrás de los nativos. Pero nosotros [se incluye él mismo autocríticamente] no estamos tanto leyendo sobre sus hombros sino que estamos escribiendo sobre sus espaldas".

Referirse a esta metáfora adquiere una conotación especial cuando pensamos que la labor antropológica se reduce a la comprensión de textos culturales. Sin embargo, la comprensión, propia de las respetables tradiciones filosóficas hermenéutica y fenomenológica, y no sólo la explicación sustentada en metodologías cuantitativas, participan en actos clasificatorios. Bajo análisis de este tipo, ocultamos y negamos aquellas experiencias humanas que desbordan o resquebrajan las conceptualizaciones con las cuales entendemos su supuesta diversidad cultural.

Es importante indicar que el debate en torno al compromiso político entre antropólogos anglosajones está entrelazado a la historia de la disciplina y a la expansión del colonialismo y el capitalismo en la era moderna. ${ }^{2}$ Por tal motivo, Wolf $(1987,33)$ es muy elocuente al sugerirnos pensar que no sólo la antropología debe ser considerada como hija del imperialismo, sino también lo son aquellas poblaciones de indígenas, campesinos pobres, jornaleros sin tierras o nacientes proletarios, que suelen estudiar antropólogos y antropólogas.

El surgimiento entonces de esos sujetos antropológicos estuvo atado a configuraciones específicas de poder, dentro de las cuales el capitalismo adquirió una especificación histórica y espacial. ¿Cómo entendieron esos procesos los antropólogos y, sobre todo, qué compromiso político esgrimieron ante la dislocación que supuso esa expansión?

Gavin Smith (1998, 47-51) tiene una respuesta a esta interrogante. ${ }^{3}$ Toma como punto de partida la existencia de una base común

${ }^{2}$ Un aspecto relevante de ese debate es la guerra de Vietnam. Acerca del papel crítico de algunos antropólogos y reacciones desde la academia norteamericana en contra de posturas políticas de profesionales de la disciplina en la denuncia de esa guerra y labores de contrainsurgencia, en las que incluso fueron reclutados antropólogos, véase a Gledhill (2000, 350-359).

${ }^{3}$ En otro trabajo, Smith (1999) busca ligar dialécticamente epistemologías surgidas en torno a relaciones sociales y modos de expresión de la cultura con visiones históricas de sociedad como parte de proyectos políticos hegemónicos y contrahegemónicos. A su 
para el estudio de la gente ordinaria, que tuvieron antropólogos e historiadores sociales antes de la década de 1950. Aunque compartieron el propósito de estudiar las culturas de esas personas, difirieron en los modos en que vincularon éstas a campos de poder. Si, por ejemplo, en Los nuer (1940), una población colonizada africana de pastores, E. E. Evans-Pritchard destacó sus instituciones y rituales, no hubo el acento necesario para su relación con específicas luchas de clase que buscaban dar un contorno a la organización colectiva (envuelta por la derrota infringida por el imperio británico), ${ }^{4}$ tal como fue realizado por las historias sociales "desde abajo" que realizaron, por ejemplo, E. P. Thompson, Eric Hobsbawm y Raymond Williams.

Smith sostiene que en el desarrollo de posturas divergentes que tuvieron un sustrato compartido en el estudio de gente subordinada, contó mucho el hecho de que esos historiadores sociales eran intelectuales políticamente comprometidos. Muchas de sus fuentes de inspiración estuvieron dadas por autores que escribieron sobre grupos subordinados del siglo XIX, tratando de destacar sus puntos de vista. Smith subraya el hecho de que en esos estudios siempre se ha vislumbrado un horizonte colectivo en la constitución de un orden social diferente ("contrahegémonico", le llama), aunque marcado por la heterogeneidad de las poblaciones subordinadas. Vislumbrar ese futuro, pudiera tener parecido con esas perspectivas utópicas que, sostiene $\operatorname{Krotz}(2002,174)$, pueden alimentar la construcción de conocimiento. Aunque sostengo que Krotz piensa más en formas organizativas ancladas en relaciones comunitarias y no verticales recreadas por cualquier proyecto hegemónico o contrahegemónico, porque finalmente significan formar un Estado, como organización central y vertical. ${ }^{5}$

modo, es una manera en que las políticas de conocimiento atraviesan tanto enfoques de antropólogos con bases "realistas" o "materialistas" como orientaciones de antropólogos posmodernos.

${ }^{4}$ Evans-Pritchard comenzó su trabajo de campo (que duró once meses) con los nuer en 1933, luego de que poco tiempo antes, en 1929, habían sido derrotados por los británicos (Vincent 2002, 30).

5 "Entonces, la tradición utópica es, esencialmente, un análisis social que, al mismo tiempo, estudia las causas de la esfera de los fenómenos culturales desde abajo y hacia delante" (cursivas en el original, Krotz 2002, 174). 
En sus últimos años de vida Pierre Bourdieu (1999), junto con el apoyo de varios colegas suyos, trató de resituar las voces de pobres, desempleados, migrantes argelinos y toda una amplia gama de seres que fueron objeto de imágenes simplistas y unilaterales de la violencia simbólica de un orden de dominación en la Francia neoliberal. En torno a esa preocupación, Bourdieu (2003) puso el problema del compromiso político a discusión en una conferencia ante antropólogos británicos. Al cuestionar la fácil autoexploración común en la etnografía posmoderna, indicó que la "experiencia vivida" o el punto de vista del sujeto que busca conocer el antropólogo debería reconstruir tanto las condiciones que lo hace posible surgir como la reconstrucción del microcosmos del analista que permite la objetivación del sujeto de investigación, en cuanto condiciona a una reflexión los conocimientos que busca generar. Situándose contra la "ortodoxia metodológica reposando bajo la autoridad de Max Weber y sus principios de neutralidad axiológica", Bourdieu sostuvo que el investigador puede y debe movilizar sus experiencias y pasado en todos sus actos de investigación, pero sólo si había rigor científico en su examen.

Curiosamente su idea de rigurosidad, planteada en el marco de esas reflexiones, giró en torno a esa posicionalidad hermenéutica con respecto a la relación intersubjetiva del investigador y el investigado. Para Bourdieu, esta posición tenía que estar a un lado de las personas -no atrás como lo sugería Geertz (al referirse metafóricamente a ellas cuando le proporcionaban sus espaldas para que él registrara e interpretara sus textos culturales)-. Esa relación más estrecha con el sujeto, representa para Bourdieu una dialógica en la que el analista reconstruye las condiciones de posibilidades que hacen surgir el punto de vista del "entrevistado" en torno a asuntos sobre su precariedad y desazón, pero en la cual el "investigador" debe tratar de ser un escucha atento y metódico para mirar qué contradicciones en torno a sí mismas revelan las clases subordinadas. En pleno predominio global del neoliberalismo, con repercusiones muy evidentes en Francia, el reputado académico Bourdieu -acaso mostrando la radicalidad propia del hijo de un cartero de una remota aldea campesina en la frontera con Espańa (Anderson 2008, 
227)- se erigió como fuerte defensor de huelguistas que se movilizaron contra medidas del gobierno para reestructurar los estándares de los compromisos de la seguridad social (Anderson 2008, 209).

Un relato diferente sobre las desigualdades humanas y formas en que se lucha contra éstas significa un compromiso político. Reconozco que esta afirmación no es ninguna novedad. He dado algunos ejemplos del carácter autocrítico que prima en algunos enfoques etnográficos. De hecho, Gledhill $(2000,382)$ sostiene como premisa para entender los poderes sociales "dejar de ocultarse tras un relativismo liberal paternalista y una postura de imparcialidad académica". Sin embargo, como sostengo también, requerimos abrir caminos hacia otras direcciones. En mi perspectiva, esto significa considerar otra forma de conocimiento que no tenga que ser valorado necesariamente como "científico". Para ello, me apoyo en dos fuentes de motivación.

La primera refiere a nuestro propio acercamiento a las historias de dominación dentro de las cuales las propias experiencias de poblaciones subordinadas han sugerido límites conceptuales y explicativos de conceptos y metodologías acerca de la operación de poderes sociales, al tiempo que su crítica demanda un replanteamiento hacia un rumbo analítico diferente. La segunda está vinculada a mi propio pasado de hijo de trabajadores textiles, cuya derrota y esperanza por lograr una vida mejor estuvieron determinadas por su definición de sujetos estatales. Además, también existe en ese pasado la aceptación de ser un analista social marginal -en buena medida por mi historia y mi posición académica en una universidad de provincia (antigua universidad de "crítica y de masas")-, cuya condición me anima a ser un crítico informado de las perspectivas dominantes metropolitanas, en estos días arropadas bajo el manto de la democracia liberal y el cosmopolitanismo.

Conceptos y SUJETOS: IMÁGENES DOMINANTES DE SOCIEDAD

Scott $(2009,73)$ emplea el término de "sujetos de Estado" para referirse a poblaciones legibles, por ser contables, medibles, así como controlables. Esta idea tiene una connotación espacial, pues indica 
la creación de zonas de Estado para favorecer la dominación. En ese marco, la constitución del margen (o las poblaciones que se ubican dentro de éste) puede tener diferentes acepciones, pero todas suponen la existencia de capas periféricas, objeto de conceptualizaciones, a veces eufemismos de pobreza, para resultar en biopolíticas, en el sentido referido por Foucault $(1979,1999,2004)$.

En el México posrevolucionario, la dominación se basó en la posibilidad de integrar regiones o sectores sociales al Estado nacional por la fuerza o el consenso. A través de la definición de un sujeto de Estado, formas diversas de autorreconocimiento y autoafirmación trataron de ser hegemonizadas, fundamentalmente por el mestizaje cultural. Valores y significados de la cultura nacional fueron objeto de interpretaciones variadas y, desde cada contexto regional, se interpretaron los significados del nacionalismo a través de soberanías locales a veces menguadas o revitalizadas por esos discursos.

En general, este proceso ha sido entendido por teóricos de la dependencia latinoamericana como colonialismo interno, lo que puede ser referido como la mimesis de un dominación espacial de la soberanía estatal en escalas más limitadas, pero que tuvieron las efectivas consecuencias de desaparecer o minar formas de comunidades relativamente autónomas y autogobernadas, eliminando o alterando con ello sus lenguas, técnicas de agricultura, prácticas religiosas, patrones de poblamiento, etcétera (véase Scott 2009, 12-13; Hewitt 1988, 166). Además, el colonialismo interno brindó el sustrato para el despliegue de la categoría de indio, esencializada racialmente, para sustentar sistemas de trabajo basados en la explotación.

$\mathrm{Si}$ la apariencia buscada era la uniformidad, en la cual los distintos escenarios territoriales de la nación se interconectaron y ensamblaron, el centralismo y autoritarismo fueron determinantes en este orden de poder. Las estructuras centralizadas basadas en organizaciones populares, compuestas de trabajadores, campesinos, estratos medios, dieron la apariencia de cuerpos políticos uniformes y la movilización tuvo como marco de expresión canales institucionales de esa burocracia corporativizada. Partidos y organizaciones de masas fueron cruciales en esas formas de modernización política, y su integración a ellos aseguraría una subjetividad leal y sumisa. 
En su conjunto, ese tipo de coherencia estuvo anclada en un sujeto estatal cuya historia y conciencia tuvo sentido en el marco de proyectos de modernización que poseyeron diversas vertientes nacionales y populistas. Varios pensadores e intelectuales cuestionaron ese orden de dominación a partir de la teoría de la democracia. La teoría de la democracia, vista "como un discurso constitutivo que ayuda a solidificar lo que es posible pensar, hacer, decir, ser, y sentir como un ciudadano" (Cruikshank 1999, 20), proporcionó los alientos suficientes para un nuevo lenguaje hegemónico sobre la política y los movimientos sociales.

El Estado autoritario y populista en México ha sido colocado en la palestra crítica teniendo como contraste los significados del liberalismo democrático y un mundo multicultural. Reflexionar sobre nuestras experiencias autoritarias ha conducido a hilar un relato crítico a través de su conversión en objeto de deconstrucción ideológica. Los alcances de esta crítica han sido vastos, pero paradójicamente han generado sus propias ideologías de identificación y dominación.

El intento clasificatorio de la teoría de los Nuevos Movimientos Sociales constituyó posiblemente el paradigma más exacto para pensar las acciones colectivas en América Latina (Laclau 1985). Ante la crisis de diferentes modalidades de Estados burocráticos autoritarios (véase O'Donnell 1996), cuya fuerza y consenso de su estructura dependió de asegurar un componente popular, por ejemplo: la clase trabajadora. Por lo tanto, referirse a la emergencia de nuevos movimientos sociales pareció oportuno en el lenguaje de las ciencias sociales. Si el pasado modernista contempló el fracaso del sujeto histórico, asociado a la vanguardia revolucionaria del partido leninista, las nuevas conceptualizaciones fueron consecuentes con la búsqueda de lo diverso, en el sentido de encontrar un sujeto plural cuyas acciones permitieran la construcción de un futuro democrático.

Entonces, hablar de nuevos movimientos sociales marcó la pauta para contemplar el surgimiento de nuevas subjetividades políticas y la emergencia de la "sociedad civil". La sociedad civil adquirió la visión hegeliana de un componente entre el Estado y el pueblo (y la familia), es decir, un medio idealizado de representación que abriría 
un amplio sitio para la expresión de la movilización democrática. Como si se tratara de la transición de los regímenes antidemocráticos de los Estados socialistas europeos, nuestros analistas e intelectuales empezaron su propia búsqueda de aquellos indicios que dieran muestra de transformaciones equiparables a los ejemplos europeos (incluida Espańa) a partir de indicar la emergencia, incluso incipiente, de la sociedad civil para llegar a tener un régimen democrático.

Esa búsqueda del sujeto plural, si la pensamos con los argumentos sugeridos por Adorno (2005, 72), se convirtió “en ideología encubridora del contexto objetivo de funciones de la sociedad y mitigadora del sufrimiento de los sujetos sometidos a ella”. El concepto de identidad para caracterizar a los movimientos sociales se convirtió en una fachada de dominio, con el objeto de definir lo que cabría dentro de las reglas sociales. Por lo tanto, se celebró la reivindicación de la diferencia y se ensalzaron las movilizaciones de minorías étnicas, feministas, ecologistas, homosexuales, que peleaban sus derechos y los realizaban, como componentes de la sociedad civil. Al fin al cabo todas eran piezas para constituir un liberalismo democrático, que tuviera como pieza ritual magna el ciclo electoral, que aseguraría la participación ciudadana y la existencia de canales y figuras para su representación.

En general, tratar de construir un relato similar no sólo en México sino en toda América Latina, parecía no sólo necesario, sino oportuno para un ajuste de cuentas con los pasados autoritarios y represivos de regímenes políticos. En este contexto de reflexión, al ligarse la formación del Estado al desarrollo surgió la crítica de pensadores posmodernos y posestructuralistas latinoamericanos en torno al peso de formaciones discursivas para esencializar a los pobres y justificar políticas de cooptación, violencia y control en regímenes de disciplina y normalización (Escobar 1995, 60, 81).

En este sentido, categorías relacionadas con el trabajo y la soberanía nacional fueron vistas como constitutivas de sujetos estatales, en tanto que campesinos, obreros, habitantes de favelas, barrios periféricos, etcétera, eran representados como objetos cuyas acciones estaban previsiblemente encasilladas en la hegemonía estatal. En 
este campo de discursos y prácticas de gobierno -ciertamente foucaultiano-, las demandas, iniciativas y organizaciones en torno al trabajo y dentro de la matriz Estado-nación han sido juzgadas como anacrónicas.

Bajo la crítica a este sujeto colectivo estatal de la modernización capitalista, se pugnó por observar la emergencia de subjetividades más capaces de desplegar valores individuales para insertarse con éxito al libre mercado en su carácter más globalizado. La evidencia de un mundo más multicultural dio sustento a ese razonamiento y subrayó el peso del concepto de cultura para la identificación política. Para nuestra generación, las visiones dominantes de las ciencias sociales nos han marcado pensar en el imperativo del cosmopolitanismo envuelto en el manto de nuestros esencialismos locales. Sobre esta lógica, el discurso hegemónico de la multiculturalidad comenzó a sentar sus bases en el paisaje político de la región y, con éste, se trataron de explicar los términos y alcances del activismo de poblaciones que reclamaban autonomía.

Imágenes conceptuales en torno a individuos en el ejercicio de sus derechos fueron más allá del sujeto nacional. Si bien éstas pudieran haber significado una crítica a la perspectiva estatista, representaron una nueva forma de coherencia sustentada paradójicamente en la fragmentación y diversidad. La nueva ola de modernización para el subcontinente estuvo relacionada con el neoliberalismo, entendido no solamente como una racionalidad económica sino también política. En este sentido, las formas de mando o soberanía estatales, pese a principios nacionalistas y populares, han estado inscritas en el contexto de los procesos globalizantes.

Tal vez lo central en esta lógica de control consista en replantear los términos del sí mismo en el gobierno de las conductas. Bajo el principio histórico del liberalismo de "menor Estado y mayor libertad del individuo", se ha establecido como componente fundamental en este valor la descentralización y la participación democrática. En este marco de referencia, por consiguiente, las "luchas" han sido entendidas conforme a principios racionales que asocien una demanda o conjunto de demandas a poblaciones perfectamente legibles en el discurso liberal de derechos y obligaciones. 
La cuestión fundamental es que en el lenguaje conceptual que surge, la búsqueda de la coherencia se da a través de la identidad cultural. Ahora la subjetividad se construye en los términos en que individuos se presentan frente a circunstancias aparentemente novedosas, por ejemplo, mercados de trabajo internacionales, desequilibrios ecológicos, replanteamiento de relaciones de género, afirmación de la etnia, descentralización de actividades del Estado a organismos administrativos locales o civiles. De ese modo, si los analistas están preparados para buscar los signos de la sociedad civil frente a la detentación del poder y la autoridad asociada a los Estados, igualmente tienen la misma disposición para discernir la identidad, cuando, por ejemplo, las personas se presentan ante sí mismas y ante los otros como indígenas en mercados de trabajo segmentados racialmente, cuando reproducen los discursos globales sobre la conservación del ambiente, afirman su género, y emprenden acciones que los "empoderan" frente a organismos estatales y otros actores.

A favor de mi argumento es necesario hacer una recapitulación sobre la crítica a los conceptos que he hecho en esta última parte. Realizo esto como una autorreflexión para formular relatos que hagan estallar conceptualizaciones que atan a las personas a formas fetichizadas que esconden relaciones de dominación.

1. Se encuentra generalizada la idea de que la movilización social debe ser conceptualizada con las premisas asociadas al carácter múltiple, fragmentado y fluido de las identidades. Por lo tanto, el concepto clave es la identidad, que puede tener los calificativos indistintos o combinados de cultural y/o política.

2. Con el uso de ese concepto y, por extensión, el desarrollo de perspectivas analíticas, se sostiene que los canales democráticos liberales parecen ser los ideales para encontrar medios de representación de los movimientos, sus agendas y aspiraciones. Así, la democracia burguesa, finalmente, es el marco para ejercer las libertades. Sus problemas, por lo tanto, son corregibles, lo cual implica un proceso contencioso en el que se ven envueltos diversos actores y fuerzas.

3. Los relatos de esta naturaleza llegan a juzgar las interacciones como propias de un campo de negociación y juego (y no de lucha como antagonismo). Los hombres y mujeres negocian con el "Esta- 
do" desde sus eventuales posiciones (la "sociedad civil" hegeliana). El Estado, entonces, es antropomorfizado, se presenta como un ente que participa en las transacciones o no, por lo cual para la gente es simultaneamente un objeto que se imagina y se concreta en la vida cotidiana (a veces concediendo demandas, a veces ejerciendo o amenazando con la violencia física). En buena medida esta fuente de inspiración se encuentra en las nombradas etnografías del Estado globalizado, llevadas a cabo y sugeridas por antropólogos formados en círculos académicos anglosajones, so pretexto de desarrollar enfoques descentrados para el estudio del poder (véase Sharma y Gupta 2006).

4. Si continuamos pensando en estos términos veremos a la democracia, su construcción, incluso con su carácter problemático, como una normalidad. Sin embargo, ésta oculta la mistificación de algo sumamente complejo: nos encontramos ante un mundo fragmentado. El capital rompe con nuestras vidas, subraya las contradicciones y genera otras entre la gente que habitualmente estudiamos. Nosotros mismos nos vemos envueltos en su fragmentación. Hacemos investigaciones "de" personas como si fueran cosas para crear el estudio más óptimo que rebase la frontera de la generación de conocimiento. En cambio, no hacemos análisis que participen en la descosificación. Participamos acríticamente en la recreación de la más desfortunada de las premisas positivistas: la escisión sujeto-objeto.

5. En este mundo más globalizado son evidentes los efectos de conceptos que llamo conceptos de identidad clasificatoria. Sostengo que el principal requerimiento científico es conceptualizar coherentemente poblaciones. Ello crea seres cuantificables o comprensibles cualitativamente (campesinos, indígenas, campesinos que se vuelven indígenas, mujeres que hacen política de género, individuos que ejercen su diversidad sexual, excluidos, marginados, ecologistas, defensores de derechos universales, etcétera). Con la reducción de las personas a estas series, categorías, objetos o cosas, se logra, en el sentido más amplio que Foucault (1999) otorga a la palabra "gubernamentalidad", ejercer sobre poblaciones distintas y clasificadas formas de gobierno o administración, sustentadas en esta era histórica, en buena medida, en la autorregulación de las conductas individuales. 
6. El desplegar tal esquema conceptual nos oculta el contexto objetivo en el que la función libertaria de la sociedad capitalista modera (o suaviza) el dolor de personas sometidas a ella. Necesitamos creer que podemos romper con esa objetivación. Tal vez podemos hacerlo si pensamos en la construcción de otro conocimiento que revele la negación de los sujetos a convertirse en abstracciones o simples cosas. Esa negación implica, en términos de la dialéctica de Marx (2001, 71-88), el reconocimiento del antagonismo de clase, el fetichismo en la forma mercancía, la cual oculta esa relación social antagónica. La mercancía tiene una doble dimensión: ser un valor de uso y un valor abstracto, lo que implica que el trabajo concreto o vivo se abstrae y se despersonaliza en una forma general de valor. La lucha, en este sentido, es una lucha por establecer y en contra de esa abstracción. Si reconocemos ese antagonismo, reconoceremos que ocultar al sujeto es una premisa positivista -liberal, conservadora o de izquier$\mathrm{da}$, si es que le quiere otorgar un nombre-. El sujeto se niega a estar oculto. Esa negación es la lucha y esa lucha es conocimiento, produce subjetividades rebeldes y desafiantes. Sin embargo, no está demás recordar la siguiente premisa de Marx (2001, 91): "El valor, en consecuencia, no lleva escrito en la frente lo que es. Por el contrario, transforma a todo producto del trabajo en un jeroglífico social”.

\section{LA OTRA EPISTEMOLOGÍA DEL SUJETO}

Cuando surgió el levantamiento armado del Ejército Zapatista de Liberación Nacional (EZLN), las conceptualizaciones hegemónicas para comprender los movimientos sociales se quedaron cortas ante la incoherencia de un evento de estas proporciones. Sencillamente, la insurrección zapatista en Chiapas desbordó los contenidos asociados a las movilizaciones de la globalización capitalista neoliberal y sugirió otras maneras de conceptuar las acciones colectivas, ahora restaurando su carácter emancipador y utópico. Por principio de cuentas, no es que faltaran palabras para explicar el zapatismo -se le llegó a llamar "posmoderno"-, una movilización propia de la sociedad civil, anacrónico, un ejemplo perfecto de los nuevos movimientos sociales o enmarcado dentro de los marcos de racionalidad 
sugeridos por sociólogos anglosajones (véase Harvey N. 2000, 3346). Sin embargo, la no correspondencia política entre un sujeto plenamente identificable como indígena y sus demandas en un mundo multicultural, accesibles éstas por no suponer la abolición de relaciones antagónicas de trabajo capitalista, replanteó literalmente desde abajo la soberanía basada en la gubernamentalidad neoliberal.

El zapatismo surgió a la luz pública los primeros días de enero de 1994, cuando tomó por las armas diversas localidades. Sus integrantes sufrieron bajas junto con la muerte de otros civiles. Sin embargo, fueron pronto repelidos por el ejército mexicano y se replegaron a zonas selváticas. Desde entonces sus acciones han adquirido un carácter pacífico y se han encaminado a la construcción de autonomía. Se trata de una forma de autonomía que busca desbordar las visiones de un mundo comunitario idealizado, es decir, sin contradicciones internas.

Los principios fundamentales de los zapatistas de Chiapas descansan en dislocar las formas de mando asociadas al orden jerárquico del Estado a través de lo que ellos llaman metafóricamente "mandar obedeciendo". También su lucha la declaran contra el capitalismo. Tal definición ha desvanecido conceptualizaciones que lo clasificaban como un movimiento "societal" que basaba sus aspiraciones en conseguir su autoafirmación cultural (Touraine 1997, 110). Sus acciones igualmente se distancian de las experiencias organizativas de un partido o vanguardia de clase leninista para concebir el cambio social desde lo que significa y ha significado la lucha para diversos sujetos que se han opuesto a categorizaciones y clasificaciones dominantes.

En el 2006, un ańo electoral para la política institucional mexicana, los zapatistas emprendieron lo que llamaron "La otra campaña”, que fue un recorrido por diversos sitios del país con el propósito de saber acerca de experiencias organizativas y luchas de distintas personas en el tiempo neoliberal. En cada lugar de arribo de "La otra campańa” se suscitó un diálogo entre los integrantes de ella y colonos, obreros, campesinos, desempleados, indígenas, trabajadoras sexuales, jóvenes banda que encontraban a su paso, mujeres al 
frente completamente de las tareas de producción y reproducción por las ausencias de los maridos, todos y todas con experiencias de exclusión y explotación comunes y particulares a sectores relacionados con esos procesos de acumulación por desposesión a los que se refiere David Harvey (2004, 116-121), los cuales han ensanchado las desigualdades y han sumido en la desesperanza a millones de personas en México y todo el mundo.

En esos eventos, los zapatistas no encontraron un relato hecho por víctimas de sus condiciones miserables y marginales, sino el recuento de actos cotidianos por evadir cualquier situación que los hiciera presa de los principios jerárquicos y de dominación establecidos por las relaciones capitalistas y el Estado. El acto dialógico de intercambiar experiencias significó la generación de un proceso de conocimiento en el cual las abstracciones en torno a hacer comprensibles los movimientos sociales a través de negar sus capacidades de lucha fueron desbaratadas. Durante los recorridos de "La otra campaña" se vislumbró la constitución de un sujeto, consciente de sus propias voces y crítico de las categorías dominantes que los han clasificado como seres abyectos y marginales.

En suma, el proceso de conocimiento desatado por "La otra campańa" colocó en aprietos a conceptos surgidos en el marco del conocimiento positivo. La violencia simbólica que ha categorizado a poblaciones para ser legibles y controlables resultó develada en las reuniones concitadas por los zapatistas, donde las abstracciones que reducen la complejidad y especificidad histórica se toparon con seres dispuestos a no ser estandarizados y controlados.

Me detengo aquí para no aparentar una idealización sobre lo que "La otra campaña" representó. Incluso, podría darse pie a pensar que mi ejemplo del zapatismo no es adecuado para establecer cómo se construye otra forma de conocimiento.

La literatura académica relativamente reciente para entender las contradicciones del zapatismo, tal como han indicado sus "críticos", parecería invalidar mi argumento (véase Estrada 2007, 22). De hecho, tales análisis tienen una consistente génesis de estudios bien planteados y sustentados en los marcos de la objetividad que harían ver débiles a los apologistas o intelectuales de tales insurrectos (véase 
Viqueira 2001). Además de los aspectos que esas investigaciones destacan con respecto a los conflictos entre comunidades de base zapatistas (numérica y objetivamente muy pocas) y otras no zapatistas o que desertaron de éstas (y que son cuantitativamente mayores), se explora también, con minuciosidad etnográfica, las contradicciones internas con respecto a los derechos individuales frente a los derechos colectivos (véase Estrada y Viqueira 2010). En otra dirección, otro tipo de investigaciones han emprendido reconocer la posición históricamente subordinada de las mujeres en relaciones patriarcales de las comunidades zapatistas o prozapatistas, así como los intentos por superarlas.

Sin duda esta discusión es muy importante, porque sobrepasa los simples límites de quien está a favor o en contra del zapatismo. Como dice una autora (Jung 2008, 11), el mundo idílico de los indígenas es amenzado por la globalización. Cualquier indígena, pero particularmente las mujeres, se encuentra enmarcado en un ambicioso neoliberalismo. Sin embargo, las mujeres se han instituido en el "sujeto emancipatorio" de nuestro tiempo. Brevemente voy a explorar esta afirmación. La sustentaré con la visión de otra autora sobre las mujeres zapatistas y la comunidad, pero también tendré presente lo que eso significa como una enseñanza de una política hecha por ellas para la emancipación de todos, algo que "La otra campaña" incitó cuando procuró que tomaran la palabra quienes quisieran, tal como pretendieron ser sus reuniones con la gente común (uno debe tener en cuenta que en muchos de los lugares por los que pasó "La otra campaña" estaban prácticamente poblados sólo por mujeres y sus pequeños hijos, debido a que sus compañeros o varones solteros jóvenes habían migrado a buscar trabajo en otros sitios, incluso en Estados Unidos).

Speed (2008, 127-135), una investigadora y activista política, piensa que la aspiración de un mundo multicultural, que implica, quiero entender, la inclusión de seres al margen de la democracia pasa por la constitución de un discurso estatal. En ese discurso, visiones eurocéntricas feministas no logran comprender las articulaciones entre los derechos individuales de las mujeres y los derechos colectivos de la comunidad zapatista para la construcción de su au- 
todeterminación. Speed expone el caso de cómo una activista local de una comunidad de base zapatista es disuadida por otras mujeres, cuando busca la promoción de su liderazgo.

Speed da cuenta de aspectos concretos de las mujeres que limitan su participación en la esfera pública: no tienen derecho a poseer tierras, a participar en las asambleas generales y están inmersas completamente en estructuras de dominación masculina. Sin embargo, destaca también cómo ellas prefieren llevar a cabo sus propias asambleas, establecer sus acuerdos y compartirlos con la comunidad. Igualmente, la autora observa que esta contradicción es reconocida por algunos hombres, quienes tratan de modificar esas relaciones asimétricas. Speed repara con esto en la densidad de las interacciones entre hombres y mujeres para resolver tales diferencias. La relación de género rebasa el esquema cultural, se haya intrincada en el contexto de poder en el cual las mujeres buscan la defensa de sus derechos como individuos a través de su autonomía como comunidad. ${ }^{6}$

A mi juicio tal discusión es valiosa. En cierta manera es coherente con la afirmación de Holloway $(2009,72)$ de ver a los zapatistas no como "objetos de estudio" de las ciencias sociales, sino como "sujetos". Desde mi perspectiva, los zapatistas crean su propio conocimiento y desbaratan los esquemas prevalecientes en las explicaciones científicas sobre ellos mismos. Dicho conocimiento no crea escuela, como un sustantivo, sencillamente es algo que se elabora sobre la marcha, a veces con la volatilidad de la oralidad, pero con el recurso siempre activo de la memoria. Ante esa debilidad por crear conocimiento como "verdad", se erige la principal virtud de generar nuevos lenguajes para desbordar lo que se piensa de nosotros, atrapados en un mundo miserable y en apariencia sin salida.

En el universo académico nos han enseñado a crear idealizaciones, pero, simultánea y paradójicamente, también a derribar mitifi-

${ }^{6}$ Hay un conjunto de estudios que intenta superar tanto idealizaciones sobre el zapatismo como interpretaciones que desestiman sus avances en la construcción de autonomía. Ejemplos de esos trabajos pueden verse en Harvey (2007); Hernández, Stephen y Speed (2006); Mora (2007); y Pérez (2004). 
caciones. A veces los estudios de caso, eso que también suele parecer como etnografía, reflejan ambas enseńanzas que constantemente se entremezclan.

En la "Declaración de La Selva Lacandona”, formulada en 2005, los zapatistas expresaron no ser un sujeto "puro", idealizado como los héroes de una resistencia. En sus palabras dijeron que, como cualquiera de nosotros, ellos están afectados por el poder. Tienen una estructura militar que no debe sobrepasar a una civil. También indicaron que se maltrata en sus pueblos a las mujeres, aunque se busca superar esto. Estos planteamientos deben verse como un indicio de autocrítica y aprendizaje. Nosotros tenemos una visión idealizada o mitificada acerca de donde no existen o no deberían existir contradicciones. Por ejemplo, el concepto que los zapatistas tienen de comunidad es uno que desborda nuestras interpretaciones. Es un concepto que reconoce lo pernicioso de las tragedias humanas y la posibilidad de finalizarlas con un replanteamiento de lo común, que también quiere decir crear y sostener relaciones sociales horizontales. En ese proceso, las mujeres son centrales. Por lo tanto, la política de ellas es ciertamente vital.

"La otra campaña” recorrió buena parte de la república mexicana. En ese trayecto, visitó rancherías, ejidos, comunidades indígenas, colonias urbanas, y se detuvo, además, en auditorios universitarios y sindicatos. Paralelo a ese desplazamiento espacial, se fueron también cristalizando los términos en que operaron esas categorizaciones gubernamentales para justificar y desatar persecuciones, uso de fuerza policiaca y encarcelamiento contra personas cuyas acciones de resistencia fueron catalogadas como peligrosas y antiinstitucionales.

De hecho, en un momento relevante de "La otra campaña", a principios del mes de mayo, fuerzas policiales reprimieron y encarcelaron a habitantes de San Salvador Atenco (que se habían opuesto con éxito a la construcción de un nuevo aeropuerto internacional en sus tierras). Ante dicho acto de violencia, "La otra campaña" fue suspendida y reorientó sus acciones para apoyar a la gente de Atenco.

Poco tiempo después, el 14 de junio en la ciudad de Oaxaca, maestros de la sección 22 que llevaban a cabo un plantón en el zóca- 
lo y calles céntricas de la ciudad para demandar la rezonificación de su salario trataron de ser sacados por la fuerza por policías del gobierno de la entidad. La violencia con la cual los agentes policíacos actuaron propició la inmediata solidaridad de diversos sectores sociales de Oaxaca. Esa represión dio origen a la Asamblea Popular del Pueblo de Oaxaca (APPO), pero no sólo la violencia contra los profesores fue su detonante. Una crisis regional de grandes proporciones mostraba fuertes dosis de autoritarismo, conflictos al interior de la elite política oaxaqueña, represión contra oponentes del gobierno de la entidad y la expresión de sentimientos de rabia y frustración que diversos sectores explotados y excluidos han vivido históricamente en la región.

La APPO estableció como demanda principal la renuncia del gobernador y posteriormente impulsó la necesidad de construir nuevas formas de participación política que tomaran distancia de las prácticas y estructuras institucionales de la democracia procedimental. Su composición heterogénea, integrada por gran cantidad de organizaciones sociales y gremiales, colonos urbanos, moradores de pueblos indígenas y campesinos, artistas, jóvenes "banda", limpiaparabrisas, niños de la calle, mujeres, estudiantes y profesionistas, logró una eventual articulación a través de operar como una gran asamblea, con una dirección colectiva y toma de acuerdos horizontales, recuperando tradiciones organizativas de comunidades indígenas.

La aparición de la APPO mostró no simplemente una respuesta coyuntural a las acciones represivas referidas, sino la posibilidad de concreción de otro tipo de comunidad política que construyera un mandato colectivo en el marco de la expresión variada de una amplia diversidad de proyectos individuales. La APPO corrió la misma suerte de los campesinos de San Salvador Atenco. Una fuerte estigmatización a sus integrantes favoreció el surgimiento de un clima de tensión regional y, en el plano nacional, justificó acciones represivas del gobierno federal contra sus integrantes.

Los despliegues de violencia estatal contra los campesinos de San Salvador Atenco y los miembros de la APPO mostraron con mayor claridad la manifestación perversa de la articulación de conocimien- 
tos, políticas y tecnologías en torno a la constitución de subjetividades acordes con los preceptos de la democracia liberal (Dean 2007, 14), centradas en la creación de una ciudadanía responsable de sí misma. En otros términos, cuando se actuó contra esas gentes se desplegó un modo de ejercer poder, un modo de gobierno, con la constitución de un campo de acción para personas que no ejercen su obligación cívica, bajo el ensamble de instituciones, conocimientos y ciudadanías en relación con el discurso de la democracia.

La narrativa dominante sobre la subjetividad democrática del ciudadano es una creación de académicos e intelectuales. Esta es una narrativa que se ha difundido y hecho popular sobre todo gracias a los medios masivos de comunicación. Tiene una fuerte base en la conformación de un enfoque de análisis "centrista" del Estado (véase Rubin 2003, 144). Según Rubin, conforme a esta visión en la historia moderna de México y, en particular, la construcción y operación de sus estructuras de dominación, se ha privilegiado la idea de ver un Estado fuerte, vertical y autoritario que aplica sus políticas sin desatar conflictos, apropiaciones o respuestas diversas. Bajo esta percepción, sitios descentralizados para confrontar el poder, por ejemplo, los marcos de la vida cotidiana y la cultura en las diversas regiones del país, no son tan relevantes para entender la construcción hegemónica del Estado nacional con todas sus contradicciones y debilidades. El meollo del enfoque centrista es la reproducción de la falsa dicotomía entre Estado y sociedad. Con el argumento de la ausencia o debilidad de una sociedad civil y, contrariamente, la fuerte presencia de un Estado central siempre proyectando una imagen vertical de poder, los ámbitos para el surgimiento de la ciudadanía prácticamente no existían.

A mi juicio, este enfoque Estado-centrista dio también base para crear una periodización de la historia de la democracia liberal moderna dividida en dos épocas. Por una parte, se identifica una fase autoritaria que nace con los procesos centralizados asociados para crear un Estado nacional en México, básicamente, a través de subrayar la existencia de un pacto social y la lealtad política de las bases populares por medio de una serie de reformas, incluida la agraria, la educación pública y el reconocimiento de los mínimos derechos la- 
borales. En la formación de este Estado posrevolucionario surgieron categorías políticas cuyas acciones se institucionalizaron en estructuras corporativas. De modo tal que construcciones culturales como campesino, indígena, marginado, fueron producto de esencializaciones políticas hechas por el Estado y las elites, refiriéndose básicamente a su condición de víctimas y actores políticamente pasivos.

La segunda época corresponde a una fase postautoritaria. Se trata de una etapa cuya génesis se remonta a la crisis del Estado posrevolucionario, visible no sólo en el resquebrajamiento de su estructura autoritaria ("la dictadura perfecta" de la que hablaba Mario Vargas Llosa), sino también a la crisis de su modelo de desarrollo ("desarrollo estabilizador") hacia el interior, que dio pie a políticas asistenciales a lo largo de varias décadas del siglo xx. Los académicos e intelectuales que ensalzan la teoría de la democracia liberal, tal como define a ésta Cruikshank (1999), suelen datar el inicio de este momento con el surgimiento del movimiento estudiantil de 1968. Este relato sobre la historia moderna de la democracia en México, al menos tuvo dos consecuencias; una, se reactivaron políticas populistas para dar paso al surgimiento después de organizaciones cívicas de diversa índole que reclamaron, paradójicamente, menos dependencia de estructuras clientelares o de cooptación; dos, surgieron movimientos radicales de izquierda que optaron por la lucha armada para lograr otra vía de cambio.

El periodo postautoritario está relacionado con el surgimiento y consolidación de las reformas estructurales impuestas al Estado mexicano por los organismos de financiamiento internacional como el Fondo Monetario Internacional y el Banco Mundial, luego de la crisis y el endeudamiento de la economía mexicana. En este periodo, no sólo son preponderantes las reformas económicas y sociales llevadas a cabo para la transformación de la naturaleza del Estado por medio de racionalidades propias de la globalización neoliberal. También las reformas políticas, básicamente con la creación de instituciones independientes para la conducción de las elecciones, han sido destacadas para ponderar las prácticas políticas novedosas de la ciudadanía. En ese contexto, el ascenso a la presidencia de un candidato de la oposición en el 2000, Vicente Fox, que representaba una ideología de 
centro-derecha, fue considerado como un corolario de la voluntad ciudadana en su tránsito hacia una sociedad democrática.

En ambas épocas, la definición que ha prevalecido de política refiere a considerar si se puede apreciar la existencia de marcos institucionales que garanticen la democracia procedimental y la participación ciudadana. En ese sentido, aquellas personas que no ejercen plenamente su ciudadanía, en ejercicios de elección democrática, están excluidos. Particularmente, el nuevo tiempo abierto con la fase postautoritaria contiene en sus elecciones la expresión ritual de un orden de poder dentro del cual, los pobres, los desposeídos, o cualquier otra categoría propia para definición de los subordinados, tienen la oportunidad para sentirse incorporados a una sociedad que, aunque de naturaleza antagónica, los representa a través de diferentes fuerzas. Por lo tanto, no participar en los actos ritualizados de la votación margina políticamente a esos sujetos y los deja sin poder (o los despolitiza).

En uno de los tantos puntos que recorrió "La otra campaña", un joven, quien se denominó a sí mismo indígena y estudiante universitario, dijo que el levantamiento zapatista de 1994 había creado una "epistemología" que en estos días podría servir para transformar "la tristeza de estar siempre subordinados" (Bellinghausen 2006). Cuando Marcos -el "Delegado Cero"- se refirió a "La otra campaña" como un "pase de lista" para saber cuáles eran las luchas de resistencia y, con ello, empezar a plantear la construcción de una red de hermandad para enfrentar al "gobierno", vislumbró la potente herramienta de los actos de "La otra campaña" en la creación de autoconocimiento del sujeto.

El pensamiento zapatista rebasó premisas deconstruccionistas para desencializar al sujeto, construido por medio de categorías ideológicas, para enriquecerlo con la objetivación de sus puntos de vista relacionados con sus historias, contradicciones, derrotas y esperanzas. Además, gracias a esa epistemología, "La otra campaña" pudo crear un relato suficientemente fuerte para comenzar a socavar la narrativa política dominante sobre los explotados y excluidos, cuya participación ciudadana en los marcos de la democracia liberal pudieran redimirlos, y para imaginar un mundo diferente impulsado por otra ética. 


\section{NARRAR LA ESPECIFICIDAD HISTÓRICA}

Al ligar los discursos de desarrollo a la formación del Estado posrevolucionario y el México moderno, uno corrobora en numerosos casos, por cierto, proporcionados por trabajos etnográficos, que estas visiones generales y abstractas sobre inclusión y democracia sólo son metanarrativas sobre el progreso y la dominación con traducciones diversas. La constitución de un relato vigoroso sobre el progreso fue traducido siempre desde los marcos de políticas locales (Zendejas 2003, 89). Las pretensiones por crear ciudadanos libres en el agro, con derechos y obligaciones, siempre quedaron atadas a las interpretaciones y acciones de elites y líderes regionales o locales (Baitenmann 2007, 72, 95). La construcción de la ciudadanía tuvo interpretaciones y construcciones variadas (Bartra 2000, 72-73; Rubin 2003, 155).

Dicha construcción, finalmente abstracta, sirvió para acentuar mecanismos de dominación caciquil y proyectos de modernización nacional, a veces débiles o a veces fuertes, articulados en escalas regionales y locales (De la Peña 1986, 31; Salmerón 1989, 212). Confrontó las nociones modernas -con matices liberales y conservadores- sobre el individuo con valores locales en torno a derechos y libertades civiles (Pansters 1997, 27). Impulsó visiones variadas sobre discursos modernizadores, ligados a políticas del Estado (Zárate 1994, 24; Zendejas y de Vries 1995). Reactivó discursos tanto comunales como liberales para el control de recursos naturales, productivos y simbólicos (Garibay 2008, 64; Roth ed. 2004). Remarcó la existencia de una lógica cultural propia con éticas para establecer lo justo y lo injusto, la cual sirvió de base para medir los agravios externos y fijar principios de autonomía realizables o potenciales (Zárate 1997).

Esas visiones uniformadoras y racionalizadoras subrayaron, sin embargo, la existencia de un mundo no secular, habitado por sus propios muertos, creencias, deidades y con el cual pudieran valorarse la expansión de lo moderno y secular (Uzeta 1997, 189-195). Pese a la uniformidad lograda por el desarrollo del capitalismo y la creación simultánea de mundos fragmentados relacionados con su mercado, 
los sujetos actuaron de maneras no orientadas a la reproducción de la lógica del capital, sino pusieron en juego una suerte de "prudencia racional" en las estrategias de sobrevivencia manifestada en torno al significado cultural conferido a ciertas mercancías en su producción y circulación en mercados regionales (véase Cook 2004, 23).

Los procesos disciplinarios ligados al capital, más que la generalización de fuertes organizaciones gremiales, se enfrentaron con trabajadores cuyas experiencia laborales estuvieron ancladas en visiones del mundo locales (Gómez 2005, 1299). El tiempo del capital más que imponerse se relacionó con rituales y cultos religiosos que desdijeron cualquier coherencia lograda por el liberalismo económico desde mediados del siglo XIX (Gómez 2007, 154-155; Henao 1980, 36-41).

No obstante que unidades productivas locales estuvieron enlazadas al mercado de producción de mercancías, generándose con ello relaciones basadas en valores de cambio, siempre sus integrantes pusieron en práctica variadas estrategias económicas para reforzar su posición y experiencia frente a esa alienación del trabajo (Cook 2004, 207). Para campesinos e indígenas en condiciones precarias, incluso para poblaciones marginales viviendo en metrópolis cosmopolitas, la reinvención de prácticas de cooperación y reciprocidad, recreando distintas redes sociales, ha sido necesaria para ajustarse a nuevas realidades económicas y novedosas situaciones de vida social que apuntalen la continuidad de sus comunidades morales, las cuales con frecuencia definen sentidos de inclusión social (véase Martínez y De la Peña 2004, 244-245).

La necesidad de tomar en serio la epistemología del otro sujeto que parece negada, me parece justificable para constituir una respuesta a ontologías que reducen al sujeto a un objeto de estudio y control. En esa misma respuesta hay una crítica contra la mistificación histórica de crear un ser homogéneo, una idea abstracta de ciudadanía, de lo que en verdad ha aparecido como de modo discontinuo, fragmentado y negado por las narrativas hegemonizantes de la teoría de la democracia. Sobre esta base ideológica, las poblaciones con visiones contrarias son presentadas como seres "incivilizados", "malos ciudadanos", sumidos en sus propios conflictos endógenos y sin conexión 
aparente con fuerzas y procesos externos. En suma, la narrativa hegemónica implica la identificación de lo no gobernable, entonces el problema de la no legibilidad de las poblaciones requiere una crítica sistemática y profunda a esa necesidad demandada por la objetividad científica de colocarse al lado de los hechos, definir a las personas como cosas y dejarlos verdaderamente sin especificidad histórica.

La metáfora de "preguntamos caminado" de los zapatistas enunciada en "La otra campaña" contiene la urgencia de encontrar respuestas sencillas y convincentes, que estén asentadas con los pies en la tierra, sobre la brutalidad de la violencia (simbólica y física) y la inmoralidad de la economía. Como intelectuales y académicos-que expresamos el origen de nuestro compromiso- tenemos la obligación de tomar en serio los conocimientos que surjan y relacionarlos con un ejercicio de autorreflexión crítica que le otorgue la profundidad y rigurosidad de la que hablaba Bourdieu, en tiempos de desolación, miseria y capitalismo triunfante. Ante la creciente proliferación en la opinión pública y académica de visiones que establecen aquello que conceptualmente es coherente para el dominio, asociado a la retórica de la democracia y el ciudadano, es más que nunca necesario hacer visible tal conocimiento que ha sido negado para integrarlo a una epistemología más compleja y documentada sobre la dominación y la lucha, incluyendo en ésta sus contradicciones internas.

\section{EPÍLOGO: DIGNIDAD COMO LUCHA Y ECOS DE OTRO CONOCIMIENTO}

$\mathrm{Al}$ intentar hacer patente otros escenarios de hacer política basada en la dignidad y la esperanza, ¿pudo "La otra campaña" lograr algo? En términos de un cambio sistémico, por supuesto que no. Sin embargo, su conocimiento sobre experiencias particulares, incluyendo las derrotas, y su organización generaron iluminaciones conectadas a una totalidad histórica y concreta. Empero, estas iluminaciones no emergieron en un panorama absolutamente oscuro. Los populistas rusos con los que dialogó Marx tenían ideas muy valiosas recogidas de sus experiencias con las comunidades campesinas para luchar 
contra el Estado y el capital. Más recientemente, poblaciones “indígenas" y campesinas de Los Altos de Bolivia han creado desde el 2001 diversos entendimientos de su pasado para situar su lucha en un horizonte que reconstruya lo común, más allá de la renovación de la articulación entre lo nacional y popular que llevan a cabo intelectuales y políticos en ese país (Gutiérrez 2008).

Marx advertía sobre la soberbia de la ciencia. Combatió tal actitud con su crítica a la economía política. La redacción del $M a-$ nifiesto comunista - pedida a él y a Engels por militantes trabajadores- planteó las contradicciones de clase que tuvieron impactos en luchas desplegadas por obreros y sectores populares en 1848 y 1871 en Europa. De las derrotas de esas luchas, los populistas rusos aprendieron mucho. En el capitalismo de nuestra era envuelto en crisis, huelguistas y desempleados en Argentina definieron, desde 2001, una forma de hacer política basada en la "horizontalidad" (hicieron asambleas, crearon comisiones de salud, educación para gobernarse "como los zapatistas"); mientras improvisaban sentados en bodegas de fábricas recuperadas, en banquetas o bancas de parques públicos lecturas de Cambiar al mundo sin tomar el poder, escrito por John Holloway (2001), un autor fuertemente inspirado por el conocimiento generado por la lucha zapatista (y no intelectual de ella).

En los últimos meses hemos visto asombrados la manifestación de movimientos caracterizados por su espontaneidad, antiautoritarismo y críticos a la reproducción de estructuras verticales de representación. En Egipto, Grecia, Espańa, incluso en el corazón financiero del mundo, Wall Street, Nueva York, los "ocupas" (The Occupy), como les gusta llamarse a sí mismos, han seguido esas prácticas. Los acuerdos se establecen por asambleas, las agendas no existen, no hay una dirección hacia donde ir, porque eso no es relevante, pues caminar, como una metáfora política, constituye experiencia. Acerca de esto, no puedo dar más detalles, pues requeriría darle mayor extensión a este trabajo.

Únicamente ofrezco dos ejemplos. El primero es acerca de un compromiso intelectual. Como dice el antropólogo David Graeber $(2012,146)$, lo que los estadounidenses ordinarios piensan en este 
momento sobre la democracia suena más claro que cuando los académicos hablan de ella. En este sentido, lo que hace Emmanuel Saez (Maclay 2012, 311-316), un economista, es recoger de las personas descontentas, aún con las enormes contradicciones presentes en la sociedad norteamericana, la idea de la existencia de $1 \%$ de personas que detentan la riqueza de este mundo contra los que se autonombran "nosotros somos el $99 \%$ \%; al mismo tiempo que indica sencillamente que hay un problema en la redistribución de la riqueza, lo cual es a todas luces inmoral.

El segundo es la referencia constante que en las asambleas de los ocupas de Nueva York se hace al zapatismo, al igual que se hizo en el cacerolazo argentino. Como sostiene Mariana Sitrin $(2011,9)$, nuestros movimientos no están sin precedentes. Por eso señala con satisfacción que por lo que a ellos corresponde, la cita de los zapatistas "Un no, muchos síes" ("One no, many yeses") es perfectamente pertinente para empezar a construir una democracia real.

Finalmente, termino con una experiencia otra vez más cercana a México en este 2012, justo en los tiempos electorales tan simbólicos para la democracia procedimental. Me refiero al surgimiento del movimiento "Yo soy 132", iniciado por jóvenes estudiantes de la Universidad Iberoamericana. Ante las acusaciones y descalificaciones de las que fueron objetos por parte de altas figuras del Partido Revolucionario Institucional (PRI), que representa lo más granado del autoritarismo mexicano, de ser reventadores de la democracia, no estudiantes, individuos entrenados y guiados por el candidato presidencial de izquierda. Como respuesta, este grupo de estudiantes subió sorpresivamente a You Tube un video donde indicaba cada uno su nombre y mostraba su credencial, sencillamente como una muestra a negarse a ser categorizado como sujetos peligrosos, por el ejercicio de una violencia simbólica amparada por la mayoría de los medios electrónicos de comunicación.

Esos estudiantes reivindicaron su derecho a protestar, su indignación por el sufrimiento de otros más desafortunados (en el acto que denostaron en su universidad al candidato presidencial del PRI, denunciaron el ataque que sufrieron los pobladores de San Salvador Atenco en el 2006). Dar un nombre, decir de donde provienen, 
manifestar lo que pueden hacer sin direcciones ni liderazgos, reunirse a través de asambleas con estudiantes de otras universidades de todo el país, así como con otras personas con experiencias distintas, parece seguir la huella con la cual la dignidad zapatista propuso construir otro conocimiento con base en las experiencias de lucha y organización de la gente de abajo.

Hasta el momento de finalizar la escritura de este ensayo, el movimiento Yo soy 132 había logrado romper con abstracciones sobre el carácter que suele darse a los jóvenes como seres apolíticos, que a lo sumo buscan su articulación en el refugio minoritario de una autoidentidad. Ciertamente en estos momentos de crisis, tragedia y dolor, en general a los jóvenes les aguarda el desempleo, violencia, trabajos mal pagados y escasas oportunidades para seguir estudiando. Una vez más, categorizaciones banales y normalizadas para referirse a quienes ni estudian ni trabajan ("nini”), están por ser desbaratadas. Los jóvenes ahora mandan un mensaje a otros para negarse a ser objetivados.

Todos estos ejemplos subrayan la importancia de reparar en el diálogo que las propias personas establecen entre sí, con sus enormes diferencias y contradicciones. Escuchemos e interactuemos con esas conversaciones. Tratemos de no estar atrás, recreando con ello una distancia entre nuestro trabajo académico y su hacer cotidiano. Tampoco busquemos colocarnos por delante con vacías conceptualizaciones que no dan cuenta de la naturaleza del antagonismo, en cuya lucha se buscan mundos más dignos y esperanzadores. Por tal razón, me atrevo a pensar que otra epistemología del sujeto más que posible, es un compromiso ético que debemos perseguir como antropólogas y antropólogos.

\section{REFERENCIAS CITADAS}

Adorno, Th. W., Dialéctica negativa-La jerga de la autenticidad, Obras completas 6, RolfTiedemann, ed., colaboración de Gretel Adorbo, Susan Bech-Morss y Klauss Schultz, Madrid, Akal Ediciones, 2005.

Anderson, Perry, "El pensamiento tibio. Una mirada crítica sobre la cultura francesa”, $C y E$, vol. 1, núm. 1, 2008, 177-234. 
Baitenmann, Helga, "Reforma agraria y ciudadanía en el México del siglo xx", en Paisajes mexicanos de la reforma agraria. Homenaje a William Roseberry, Francisco Javier Gómez Carpinteiro, ed., Zamora, El Colegio de Michoacán, 2007.

Bartra, Armando, Guerrero bronco. Campesinos, ciudadanos y guerrilleros en la Costa Grande, México, ERA, 2000.

Bellinghausen, Hermann, "'Los indígenas ya no vamos a pedir perdón ni compermiso': mazahuas” en http://www.jornada. unam.mx/2006/04/23/index.php?section=politica\&article=01 2n1 pol, consultado el 6 de noviembre, 2008.

Bourdieu, Pierre, dir., La miseria del mundo, Madrid, Akal Ediciones, 1999.

, "Participant objetivation", Journal of the Royal Anthropological Institute, 2003, versión documento electrónico, http:// www. Accessmylibrary.com/coms2/summary, consulta 10 de enero, 2008.

Cook, Scott, Understanding Commodity Cultures. Explorations in Economic Anthropology with Cases Studies from Mexico, Nueva York, Rowma \& littlefield Publishers, Inc., 2004.

Cruikshank, Barbara, The Will to Empower. Democratic Citizens and Other Subjects, Ithaca, Nueva York y Londres, Cornell University Press, 1999.

D’Andrade, Roy, "Moral Models in Anthropology", Current Anthropology, vol. 16, núm. 3, 1995, 399-408.

Dean, Mitchel, Governing Societies: Political perspectives on domestic an international rule, Londres, Mc Graw Hill, Open University Press, 2007.

De la Peña, Guillermo, "Poder local, poder regional: perspectivas socioantropológicas", en Poder local, poder regional, Jorge Papua y Alain Vanneph, eds., México, El Colegio de México, CEMCA, 1986.

Escobar, Arturo, Encountering Development. The Making and Unmaking of the Third World, Nueva Jersey, Princeton, Princeton University Press, 1995.

Estrada SaAvedra, Marco, La Comunidad armada rebelde y el EZLN. Un estudio histórico y sociológico sobre las bases de apoyo zapa- 
tistas en las cañadas tojolabales de la Selva Lacandona (19302005), México, El Colegio de México, 2007.

Estrada Saavedra, Marco y Juan Pedro Viqueira, coord., Los indígenas de Chiapas y la rebelión zapatista. Microhistorias politicas, México, El Colegio de México, 2010.

FouCAult, Michel, Vigilary castigar: nacimiento de la prisión, México, Siglo XXI Editores, 1979.

"La gubernamentalidad", en Estética, ética y hermenéutica. Obras esenciales, Volumen III, Barcelona, Paidós, 1999.

Historia de la sexualidad. 1. La voluntad del saber, México, Siglo XXI Editores, 2004.

Garibay Orozco, Claudio, Comunalismos y liberalismos campesinos. Identidad comunitaria, empresa social forestal y poder corporado en el México contemporáneo, México, El Colegio de Michoacán, 2008.

GeERTz, Clifford, La interpretación de las culturas, Barcelona, Gedisa Editorial, 1990[1973].

GledHILl, John, El poder y sus disfraces, Barcelona, Ediciones Bella Terra, 2000.

Gómez Carpinteiro, Francisco Javier, "La modernidad contendida. Estado, comunidades rurales y capitalismo en la posrevolución", Mexican Studies/Estudios Mexicanos, vol. 21, núm. 1, 2005, 97-139.

, "Comunidades de agua en el Nexapa. Liberalismo y centralización en el control de recursos hidráulicos", en Paisajes mexicanos de la reforma agraria. Homenaje a William Roseberry, Francisco Javier Gómez Carpinteiro, ed., México, El Colegio de Michoacán, 2007.

Graeber, David, “Occupy Wall Streets Anarchist Roots", en The Occupy Hand Book, Janet Byrne, ed., Nueva York, Boston, Londres, Little, Brown and Company, 2012.

GutiérRez Aguilar, Raquel, Los ritmos del pachakuti: levantamiento y movilización en Bolivia (2000-2005), ICSyH-BUAP, México, Bajo Tierra Ediciones, Sísifo Ediciones, 2009.

Hale, Charles R., "Más allá que un indio". Ambivalencia racial y multiculturalismo neoliberal en Guatemala, Guatemala, Instituto AVANCSO, 2007. 
Harvey, David, El nuevo imperialismo, Madrid, Akal, 2004.

Harver, Neil, La rebelión de Chiapas. La lucha por la tierra y la democracia, México, Editorial Era, 2000.

, "La difícil construcción de la ciudadanía pluriétnica: el zapatismo en el contexto latinoamericano", Liminar. Estudios Sociales y Humanisticos, núm. 5, 2007, 9-23.

Hernández, Aída, Lynn Sthephen y Shannon Speed, eds., Dissident Women: Gender and Culture Politics and Chiapas, Austin, University Texas Press, 2006.

Henao, Luis Emilio, Tehuacán: Campesinado e irrigación, México, Edicol, 1980.

Hewitt de Alcántara, Cynthia, Imágenes del campo. La interpretación antropológica del México rural, México, El Colegio de México, 1988.

HollowaY, John, Cambiar al mundo sin tomar el poder. El significado de la revolución hoy, México, Herramienta, BUAP, 2002.

, "El zapatismo y las ciencias sociales en América Latina", en La rosa roja de Nissan y otros escritos, textos rebeldes, Bolivia, La Paz, 2009.

Jung, Courtney, The Moral Force of Indigenous Politics. Critical Liberalism and the Zapatistas, Nueva York, Cambridge University Press, 2008.

KROTZ, Esteban, La otredad cultural entre utopia y ciencia. Un estudio sobre el origen, el desarrollo y la orientación de la antropología, México, Universidad Autónoma Metropolitana Unidad Iztapalapa, Fondo de Cultura Económica, 2002.

LAClaU, Ernesto, "New Social Movements and the Plurality of the Social, en David Slater, ed., New Social Movements and the State in Latin America, Amsterdan, CEDLA, 1985.

MacLaY, Kathleen, "Interview with Emmanuel Saez", en Janet Byrne, ed., The Occupy Hand Book, Nueva York, Boston, Londres, Little, Brown and Company, 2012.

Martínez Casas, Regina y Guillermo de la Peña, "Migrantes y comunidades morales. Resignificación, etnicidad y redes sociales en Guadalajara (Méjico), Revista de Antropología Social, Madrid, Universidad Complutense, vol. 13, 2004, 217-251. 
MARx, Carlos, El capital, tomo I, vol. 1, Libro primero, 24ª edición, México, Siglo XXI Editores, 2001.

MorA, Mariana, "Zapatista Anticapitalist Politics and the 'Other Campaign'. Learning from the Struggle for Indigenous Rights and Autonomy", Latin American Perspectives, 153, vol., 34, núm. 2, 2007, 64-77.

O’Donnell, Guillermo, El Estado burocrático autoritario. Triunfos, derrotas y crisis, Buenos Aires, Editorial de Belgrano, 1996.

Ortner, Sherry B., "Resistance and the Problem of Ethnographic Refusal", en Anthropology and Social Theory. Culture, Power and the Acting Subject, Durham y Londres, Duke University Press, 2006.

PAnsters, Wil G., "Ciudadanos con dignidad. Oposición y gobierno en San Luis Potosí 1938-1993", en Movimientos sociales e identidades colectivas. México en la década de los noventa, Sergio Zermeño, coord., México, La Jornada ediciones y Centro de Investigaciones Interdisciplinarias en Ciencias y Humanidades, UNAM, 1997.

Pérez Ruiz, Maya Lorena, ed., Tejiendo historias. Tierra, género y poder en Chiapas, México, INAH, 2004.

Roth Seneff, Andrew, ed., Recursos contenciosos. Ruralidad y reformas liberales en México, México, El Colegio de Michoacán, 2004.

Rubin, Jeffrey W., "Descentrando el régimen: cultura y política regional en México", Relaciones. Estudios de Historia y Sociedad, Zamora, El Colegio de Michoacán, núm. 96, 2003, 127-180.

Salmerón Castro, Fernando, Los limites del agrarismo. Proceso político y estructuras de poder en Taretan, Michoacán, México, El Colegio de Michoacán, 1989.

Scheper-Hughes, Death without Weeping, Berkeley, University of California Press, 1992.

Scotт, James C., The Art of not being Governed. An Anarchist History of Upland Southeast Asia, New Haven y Londres, Yale University Press, 2009.

Sitrin, Mariana, “One No, Many Yeses”, en Occupy! Scenes from Occupied America, editado por Astra Taylos, Keith Gessen y editores de n más 1, Londres, Nueva York, Verso, 2011. 
Shanin, Teodor, "Marxim and the Vernacular Revolutionary Traditions", en Late Marx and the Russian Road: Marx and the Peripheries of Capitalism, Teodor Shanin, ed., Londres, Routledgeand Keagan Paul, 1983.

Sharma, Aradhana y Akhil Gupta, "Introduction: Rethinking Theories of the State in an Age of Globalization", en The Anthropology of the State. A Reader, Oxford, Blackwell Publishing, 2006.

SMith, Gavin, "Los contornos de la actividad colectiva: El papel de la organización y la interpretación”, en La disputas por el México rural. Transformaciones de prácticas, identidades y proyectos, Sergio Zendejas y Pieter de Vries, ed., México, El Colegio de Michoacán, 1998.

SpeED, Shanon, Rights in Rebellion. Indigenous Struggle and Human Rights in Chiapas, Stanford, Stanford University Press, 2008.

Touraine, Alain, ¿Podremos vivir juntos? Iguales y diferentes, México, Fondo de Cultura Económica, 2000.

Trouillot Michel-Rolph, "Making Sense: The Fields in wich We Work", en Global Transformatiosn. Anthropology and the Modern World, Inglaterra, Palgrave Macmillan, 2003.

UzETA, Jorge, "El diablo y la santa. Imaginario religioso y cambio social en Santa Ana Pacueco, Guanajuato, México”, en José Eduardo Zarate Hernández, ed., Bajo el signo del Estado, Zamora, El Colegio de Michoacán, 1997.

Vincent, Joan, ed., The Anthropology of Politics. A Reader in Ethnography, Theory, and Critique, Malden, Blackwell Publishers, 2002. Viqueira, Juan Pablo, "Chiapas la otra bibliografía”, Letras Libres, núm. 25, 2001, 89-95.

Wolf, Eric R., Europa y la gente sin historia, México, Fondo de Cultura Económica, 1987[1982].

Zarate Hernández, José Eduardo, Los señores de la utopía. Etnicidad politica en una comunidad p'urhépecha: Santa Fe de la Laguna-Ueamuo, México, El Colegio de Michoacán, 1994.

- Procesos de identidad y globalización económica. El Llano Grande en el Sur de Jalisco, México, El Colegio de Michoacán, 1997. 
Zendejas Romero, Sergio, "Política local y formación del Estado. Procesos históricos de formación de espacios y sujetos sociales, 1914-1998", Tesis de doctorado, Universidad Wageningen, 2003. ZENDEJAs, Sergio y Pieter DE VRIEs, eds., Rural Transformations seem from Below: Regional and Local Perspectives from Western Mexico, San Diego, Center for U.S.-Mexican Studies, University of California, 1995.

FECHA DE RECEPCIÓN DEL ARTí́culo: 20 de febrero de 2012 Fecha de aprobación: 6 de julio de 2012

FECHA DE RECEPCIÓn DE LA VERSIÓN FINAL: 19 de septiembre de 2012 